\title{
COVID-19'da gastrointestinal semptomlar ile hastalığın seyri ve prognozu arasında bir ilişki var mı? Tek merkezli pilot çalışma
}

\author{
Is there a relationship between gastrointestinal symptoms and disease course and prognosis in \\ COVID-19? A single-center pilot study
}

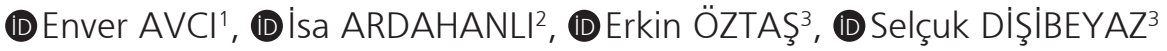

Bilecik Devlet Hastanesi, ' Gastroenteroloji Kliniği, ${ }^{2}$ Kardiyoloji Kliniği, Bilecik

Osmangazi Üniversitesi Tıp Fakültesi, ${ }^{3}$ Gastroenteroloji Kliniği, Eskişehir

Giriş ve Amaç: Pandemi yapan ve çok fazla ölüm nedeni olan COVID-19 genelde solunumsal semptomlarla prezente olsa da bazen bu semptomlara gastrointestinal semptomlar da eşlik etmektedir. Çalışmamızda COVID-19 hastalarında gastrointestinal semptomların sıkığını ve prognozla ilişkisini araştırmayı amaçladık. Gereç ve Yöntem: 11 Mart 2020-30 Nisan 2020 tarihleri arasında Bilecik Devlet Hastanesine başvuran ve real time polimeraz zincir reaksiyonu ile tanısı konulan 110 hastanın demografik, radyolojik, laboratuvar ve klinik açıdan analizi yapıldı. Bulgular: Hastaneye başvuru esnasında 13 (\%11.8) hastada bir veya daha fazla gastrointestinal semptom vardı. Biyokimyasal parametrelerden D-dimer ve fibrinojen artışıly gastrointestinal semptomlar arasında belirgin ilişki vardı $(p<0.001)$. gastrointestinal semptom varlığı hastalık şiddeti ile ilişkiliydi ( $p=0.012)$ ve hastalık şiddetini öngörmede yüksek prediktif değere sahipti (Odds Ratio=7.2). Sonuç: COVID-19 nadiren sadece gastrointestinal semptomlarla prezente olabilmektedir. Pandemi döneminde gastrointestinal semptomu olan hastalarda COVID-19 akIda tutulmalı ve sağlık çalışanları bu konuda uyanık olmalıdır ve korunma adına gerekli tedbirlerini almalıdırlar. Ayrıca bu hastaların erken tespit edilmesi ile hastalığın daha fazla yayılması engellenebilecektir.

Anahtar kelimeler: COVID-19, gastrointestinal semptomlar, hastalık şiddeti

\section{GíRiş}

Aralık 2019'da Çin'in Wuhan Şehrinde yeni bir korona virüs (COVID-19) pnömonisi ortaya çıktı ve kısa sürede tüm Dünya'ya yayıldı. Hastalık 11 Mart 2020 tarihinde Dünya Sağlık Örgütü (WHO) tarafından pandemi olarak ilan edildi. Uluslararası Virüslerin Taxonomisi Komitesi tarafından virüse "ciddi akut solunum sendromu koronavirus (SARS-CoV-2)" adı verildi (1). Hastalık hızlı bir şekilde tüm Dünya'ya yayılmış, milyonlarca insanı enfekte etmiş ve çok fazla sayıda insanın ölümüne neden olmuştur.

COVID-19 çoğu zaman sadece üst solunum yolu semptomlarıla prezente olurken bazen de hafif pnömoni, şiddetli pnömoni, akut solunum yetmezliği ve çoklu organ

Iletişim: Enver AVCI

Bilecik Devlet Hastanesi, Gastroenteroloji Bölümü, Bilecik

E-mail: enver.a.dr@gmail.com
Background and Aims: Although COVID-19 pandemic that causes many deaths is usually presented with respiratory symptoms, the symptoms are often accompanied by gastrointestinal symptoms. In our study, we aimed to investigate the frequency of gastrointestinal symptoms in COVID-19 patients and their relationship with prognosis. Materials and Methods: Demographic, radiological, laboratory, and clinical analyses were conducted on 110 patients who submitted to Bilecik State Hospital between 11 March 2020 and 30 April 2020. Furthermore, a real-time polymerase chain reaction was used to diagnose COVID-19. Results: During hospital admission, 13 (11.8\%) patients had one or more gastrointestinal symptoms. There was an increase in the occurrence of gastrointestinal symptoms with age $(p=0.062)$. In addition, there was a strong correlation between GI symptoms with D-dimer and fibrinogen increase from biochemical parameters $(p<0.01)$. The occurrence of gastrointestinal symptoms was associated with disease severity $(p=0.012)$ and had a high predictive value when predicting disease severity $(O R=7.2)$. Conclusion: COVID-19 can rarely be presented with only gastrointestinal symptoms. Moreover, COVID-19 should be kept in mind in patients with gastrointestinal symptoms during the pandemic period, and health workers should be cautious and take appropriate precautions for protection. In addition, early identification of these patients will prevent further spread of the disease.

Key words: COVID-19, gastrointestinal symptoms, disease severity

hasarı gibi geniş bir spektrumda kendini gösterebilmektedir (2). COVID-19 her ne kadar ön planda solunumsal semptomlara yol açıyor olsa da bazı hastalarda solunum dışı semptomlara da yol açabilmektedir. Bu semptomların bir kısmı gastrointestinal (GI) sistem ile ilgili olup bunlar bulantı, kusma, karın ağrısı ve diyare şeklindedir (3-5). Bazen de COVID-19 hiçbir solunumsal semptom göstermeden sadece Gl semptomlarla prezente olabilmektedir (6).

Gl semptomları olan hastaların hastaneye başvuru sürelerinin Gl semptomu olmayanlara göre daha geç olduğu (5), dışkıda SARS-CoV-2 genomu saptananlarda viral klirensin daha uzun sürdüğü bildirilmiştir (7).

Avcı E. Ardahanlı i, Öztas $E$, et al. Is there a relationship between gastrointestinal symptoms and disease course and prognosis in COVID-19? A single-center pilot study. The Turkish Journal of Academic Gastroenterology 2020;19:103-108. DOI: 10.17941/agd.847338

Geliş Tarihi: 18.11.2020 • Kabul Tarihi: 22.12.2020 
Yapılan çalışmalarda COVID-19'da GI semptom görülme sıklığı değişik oranlarda saptanmış olup Gl semptomların hastalık prognozu üzerine etkisi konusunda da farklı sonuçlar bulunmuştur (5,8-10). Biz çalışmamızda COVID-19 tanılı hastalarda GI semptomların sıklı̆ını, bu hastalarda hastalık seyrini ve GI semptomların prognozu öngörmedeki değerini araştırmayı amaçladık.

\section{GEREÇ ve YÖNTEM}

Çalışma retrospektif şekilde 11 Mart 2020-30 Nisan 2020 tarihleri arasında Bilecik Devlet Hastanesinde tek merkezli olarak retrospektif tarzda yapılmıştır. Çalışmaya 110 COVID-19 enfeksiyonu olan hasta dahil edildi. Çalışmaya sadece real time polimeraz zincir reaksiyonu (RT-PCR) pozitif hastalar alınmıştır.

Hastalar COVID-19 şiddetine göre 3 gruba ayrıldı. Buna göre solunum yolu semptomları olan ancak bilgisayarlı tomografide (BT) pnömonisi olmayanlar hafif şiddetli,

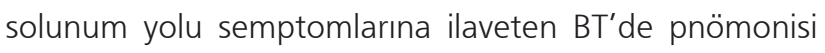
olanlar orta şiddetli, solunum yetmezliği gelişip yoğun bakıma alınanlar ise şiddetli grup olarak sınıflandırımıştır.

Toraks BT'de COVID-19 pnömonisi ile uyumlu BT diyebilmek için tipik kriterler kullanımıştı; Bunlar buzlu cam görünümü, bilateral olma, periferal ve dorsal tutulum, kaldııım taşı görünümü, hava bronkogramı, vasküler genişleme, konsolidasyon, bronş değişiklikleri, peribronkovasküler dağılım, daha çok orta, alt zonlarda ve multilober olma şeklinde idi (11).

Gastrointestinal semptomlar olarak bulantı, kusma, diyare ve karın ağrısı değerlendirmeye alınmış olup günde $>3$ 'ten fazla gevşek dışkılama diyare olarak kabul edilmiştir.

Çalışma dışlama kriterleri; başlangıçta toraks BT çekilmemiş olması, hastaneye başvurmadan önce antibiyotik ve nonsteroid anti-inflamatuvar ilaç kullanılmış olması, aktif dönemde inflamatuvar barsak hastalığı, diyare baskın irritabl barsak sendrom ve kronik karaciğer hastalığı varlığı olması idi.

RT-PCR testleri tersiyer merkez olan Bursa Şehir Hastanesi Mikrobiyoloji Laboratuvarında yapılmıştı. Bu amaçla alınan nazofarengeal sürüntüler viral transport besiyerine (virokült) konulmuş ve soğuk zincirde bu laboratuvara götürülmüştü. Burada SARS-CoV-2 genomu \%99.4 sensitivite, \%99.0 spesifiteye sahip RT-qPCR tespit kiti kullanılarak araştııı ımış ve test sonuçları yaklaşık 24-48 saat sonra Sağlık Bakanlığı Halk sağlı̆ı Yönetim Sistemine (HSYS) aktarılmıştı. Tarafımızca HSYS kayıtları yeniden incelenerek RT-PCR sonuçları kontrol edildi.
Hastaların tümüne başvuru anında kontrastsız toraks BT çekilmişti. Hastaların BT'leri yeniden incelenerek COVID-19 ile uyumlu pnömoni bulguları olanlar hasta verilerini bilmeyen bir radyolog tarafından değerlendirilerek tanılar konfirme edildi.

Hastalara tam kan sayımı yapıldı. Biyokimyasal parametreleri venöz kan örneklerinden ölçüldü. Kan örneklerinde aspartat aminotransferaz (AST), alanin aminotransferaz $(\mathrm{ALT})$, gama glutamil transferaz (GGT), laktat dehidrogenaz (LDH), C-reaktif protein (CRP), D-dimer, fibrinojen, ferritin total ve direkt bilirübin, sodyum, potasyum, üre, kreatinin değerlendirildi.

Hastaların tıbbi özgeçmişleri hastane bilgi sisteminden alındı. Öykülerinde eksiklik olan hastalardan halen yatmakta olanlar için serviste takip eden hekiminden, yoğun bakımda yatanlar için birinci derece yakınlarından, taburcu olmuş hastalar ise telefonla aranarak eksik bilgileri tamamlandı.

Çalışmamızda hastaların demografik, radyolojik, laboratuvar parametrelerini, klinik bulgularını ve hastalı̆ın sonuçlarını (taburcu, mekanik ventilasyon ve ölüm) topladık ve bunları analiz ettik.

\section{İstatiksel Yöntem}

Tüm sürekli ölçümler normallik için Shapiro-Wilk testi ile değerlendirildi. Normal dağılım gösteren değişkenlerin karşılaştııılmasında bağımsız örnekler Student t testi, normal dağılmayan sürekli değişkenlerin karşılaştırımasında ise Mann-Whitney $U$ testi kullanılmıştır. Kategorik değişkenler ki-kare analizi kullanılarak karşılaştıııldı. P $<0.05$ değişkenlerinin sonuçları istatiksel olarak anlamlı kabul edildi. İstatiksel analizler IBM SPSS statistics 22 sürümü kullanılarak yapıldı.

\section{Etik Onay}

Çalışmanın etik kurul onayı Türkiye Cumhuriyeti Sağlık Bakanlığı etik kurulu tarafından 2020_05_11T21_25_32 karar numarası ile 16.05.2020 tarihinde alınmıştır. Çalışma Helsinki Deklarasyon Prensiplerine uygun şekilde yapılmışır.

\section{BULGULAR}

Hastalar demografik, klinik ve laboratuvar parametreler açısından değerlendirildiğinde, hastaların 32'si (\%29.1) kadın, 78'i (\%70.9) erkekti. En küçüğü 16 en büyüğü 85 yaşında olup yaş ortalaması 38.5 \pm 18.15 yıl idi. Başvuru esnasında 53 (\%49.2) hasta orta ve şiddetli hastalı̆̆a, 57 (\%51.2) hasta ise hafif şiddette hastalığa sahipti. Hastalığı daha şiddetli olanların 16'sı (\%30.2) kadın, 37'si (\%60.8) erkekti. 
Hastalık şiddetiyle; yaş, AST, GGT, LDH, CRP, D-dimer, fibrinojen ve ferritin değerlerindeki yükseklik, lenfosit ve monosit değerlerindeki düşüklük ile anlamlı ilişki varken; cinsiyet, ALT, bilirübinler, lökosit ve nötrofil değerleriyle istatiksel olarak anlamlı ilişki yoktu ( $p<0.05$, $p>0.05$ sırasıyla) (Tablo 1).

Hastaların takibinde; başlangıçta hafif şiddette hastalığı olanların hiçbirinin kliniğinde kötüleşme olmazken, orta şiddette hastalığı olanlardan biri serviste ani ölümle kaybedilirken, 5 tanesi yoğun bakıma alındı ve hepsi izlemde entübe edilip mekanik ventilatöre bağlandı. Entübe olanlardan 2 tanesi ölürken, 3 tanesi ekstübe olup sonrasında taburcu oldu.

Başvuru esnasında 13 (\%11.8) hastada bir veya daha fazla Gl semptom vardı. Gl semptomlar olarak; 10 (\%9.1) hastada diyare, 10 (\%9.1) hastada bulantı, 8 (\%7.3) hastada kusma ve 2 (\%1.8) hastada karın ağrısı vardı. Bir (\%0.9) hastada ise dört GI semptomunun hepsi bulunuyordu.

Gl semptomu olan ve olmayan hastalar demografik, radyolojik, laboratuvar ve klinik açıdan değerlendirildiğinde; cinsiyet ile Gl semptom sıklığı arasında ilişki yokken ( $p=0.505)$, yaş artışıyla GI semptom görülme sıklığı arasında istatiksel olarak hafif bir ilişki vardı (47.5 \pm 18.3 , 37.5 \pm 17.85 sırasıyla; $p=0.062$ ).

Gl semptomu olan ve olmayan hastalar başvuru BT'deki pnömoni şiddeti açısından karşılaştıııldığında iki grup arasında tutulum ve şiddet açısından farklılık yoktu. İki grupta da tutulum bilateraldi ve benzer şiddetteydi.

Hastalar laboratuvar parametreleri açısından değerlendirildiğinde, GI semptomu olan grupta GI semptomu olmayan gruba göre LDH $(275.5 \pm 97.9$ vs $232.6 \pm 158.5$, sırasıyla; $p=0.032), \operatorname{CRP}(30.1 \pm 21.2$ vs $22.7 \pm 43.1$, sırasıyla; $p=0.017)$, D-dimer (1108.9 \pm 1310.9 vs $675.1 \pm 1619.8$, sırasıyla; $p=0.006)$, ferritin $(223.7 \pm 357$ vs $370.8 \pm 416.8$ sirasılya; $p=0.073)$ ve fibrinojen $(475.8 \pm 199.8$ vs 338.77 \pm 159 , sırasıyla; $p=0.006$ ) değerleri anlamlı şekilde daha yüksekti. AST, ALT, GGT, direkt ve total bilirübinler, beyaz küre, lenfosit ve monosit değerleri açısından her iki grup arasında istatiksel olarak anlamlı farklılık yoktu (her biri için $p>0.05$ ). Gl semptom olan ve olmayan hastaların parametrelerle karşılaştırılması Tablo 2'de verilmiştir.

Hastalığın klinik şiddeti ile Gl semptomların varlığı ilişkisi için yapılan değerlendirmede; Gl semptomlar orta ve şiddetli hastalığı olan grupta hafif şiddette hastalığı olan gruba göre daha fazlaydı ve bu istatiksel olarak anlamlıydı $n=11(\% 20.8), n=2(\% 3.5)$ sırasıyla, $p=0.012]$.

Tablo 1. COVID-19'daki parametrelerin karşılaştırılması

\begin{tabular}{|c|c|c|c|}
\hline & Hafif (57) & Orta ve Şiddetli (53) & p Değeri \\
\hline Yaş (yıl) & $28.12 \pm 10.22$ & $49.60 \pm 18.29$ & $<0.001$ \\
\hline Cinsiyet (kadın), n, \% & $16(28 \%)$ & $16(43 \%)$ & 0.973 \\
\hline $\operatorname{AST}(\mathrm{U} / \mathrm{L})$ & $27.74 \pm 13.28$ & $42.04 \pm 38.64$ & 0.013 \\
\hline $\operatorname{ALT}(\mathrm{U} / \mathrm{L})$ & $29.74 \pm 32.50$ & $41.23 \pm 56.09$ & 0.188 \\
\hline GGT (U/L) & $31.46 \pm 13.99$ & $47.09 \pm 35.01$ & 0.003 \\
\hline $\mathrm{LDH}(\mathrm{U} / \mathrm{L})$ & $192.14 \pm 74.55$ & $284.81 \pm 195.43$ & 0.002 \\
\hline T. bil. (mg/dl) & $0.66 \pm 0.18$ & $0.69 \pm 0.36$ & 0.501 \\
\hline D. bil. (mg/dl) & $0.15 \pm 0.71$ & $0.17 \pm 0.11$ & 0.356 \\
\hline $\mathrm{CRP}(\mathrm{mg} / \mathrm{dl})$ & $5.83 \pm 12.9$ & $42.31 \pm 51.39$ & $<0.001$ \\
\hline $\mathrm{d}$-Dimer $(\mathrm{ng} / \mathrm{ml})$ & $244.6 \pm 138.6$ & $1236.8 \pm 2166.8$ & 0.002 \\
\hline WBC $\left(/ \mathrm{mm}^{3}\right)$ & $7329.1 \pm 2612.3$ & $7099.06 \pm 3211.2$ & 0.68 \\
\hline Nötrofil $\left(/ \mathrm{mm}^{3}\right)$ & $4463.8 \pm 2240.9$ & $4630.9 \pm 3020.1$ & 0.741 \\
\hline Lenfosit $\left(/ \mathrm{mm}^{3}\right)$ & $2182.6 \pm 887.8$ & $1723.4 \pm 808.8$ & 0.06 \\
\hline Monosit $\left(/ \mathrm{mm}^{3}\right)$ & $514.2 \pm 166.7$ & $443.5 \pm 188.7$ & 0.04 \\
\hline Ferritin (ng/ml) & $109.86 \pm 51.52$ & $380.34 \pm 487.04$ & $<0.001$ \\
\hline Fibrinojen (mg/dl) & $274.05 \pm 78.1$ & $440.58 \pm 196.2$ & $<0.001$ \\
\hline
\end{tabular}

AST: Aspartat aminotransferaz, ALT: Alanin aminotransferaz, GGT: Gama glutamil transpeptidaz, LDH: Laktat dehidrogenaz, T. Bil.: Total bilirübin, D. Bil.: Direkt bilirübin, CRP: C-reaktif protein, WBC: Lökosit. ( $P<0.05$ istatiksel anlamlılık) 
Klinik takipte 110 hastanın 6'sında yoğun bakım ünitesine (ICU) alınma, mekanik ventilasyon (MV) ihtiyacı ve ölüm oluştu. Gl semptomu olan 13 hastanın 1 (\%7.7) tanesinde sonlanım noktası gelişirken, GI semptomu olmayan 97 hastanın 5 (\%5.2) tanesinde sonlanım noktası gelişti. Yapılan istatiksel analizde GI semptom ile sonlanım noktaları arasında istatiksel olarak anlamlı ilişki yoktu $(p=0.539)$.
Gl semptomlar ile hastalık şiddeti arasında ilişki olup olmadığını belirlemek için multivaryant lojistik regresyon analizi yapıldığında, Gl semptomların hastalık şiddetini öngörmede yüksek prediktif değere sahip olduğu saptandı [Odds Ratio $(O R)=7.2$, güven aralığı $(\mathrm{Cl}) \% 95=1.51$ $34.24 p=0.012]$. Prediktif değeri olan tüm parametreler Tablo 3'de verilmiştir.

Tablo 2. Şiddetli COVID-19 için multivaryant regresyon analizi

\begin{tabular}{|lccc} 
& P-değeri & OR & $\mathbf{9 5 \%} \mathbf{C l}$ \\
\hline Gl semptomlar & 0.012 & 7.2 & $1.515-34.24$ \\
\hline Yaş (yll) & $<0.001$ & 1.104 & $1.063-1.147$ \\
\hline AST $(\mathrm{U} / \mathrm{L})$ & 0.013 & 1.046 & $1.011-1.083$ \\
\hline CRP $(\mathrm{mg} / \mathrm{L})$ & $<0.001$ & 1.04 & $1.022-1.077$ \\
\hline GGT $(\mathrm{U} / \mathrm{L})$ & 0.003 & 1.032 & $1.009-1.056$ \\
\hline Ferritin $(\mathrm{ng} / \mathrm{ml})$ & $<0.001$ & 1.011 & $1.005-1.017$ \\
\hline LDH $(\mathrm{U} / \mathrm{L})$ & 0.002 & 1.01 & $1.004-1.017$ \\
\hline Fibrinojen $(\mathrm{mg} / \mathrm{dl})$ & $<0.001$ & 1.01 & $1.006-1.015$ \\
\hline D-dimer $(\mathrm{ng} / \mathrm{ml})$ & 0.002 & 1.006 & $1.003-1.009$ \\
\hline
\end{tabular}

OR: Odds ratio, Cl: Güven aralı̆̆ı, GI: Gastrointestinal, AST: Aspartat aminotransferaz, CRP: C-reaktif protein, GGT: Gama glutamil transpeptidaz, LDH: Laktat dehidrogenaz. ( $(P<05$ istatiksel anlamlllik)

Tablo 3. GI semptomları olan ve olmayanların karşılaştırılması

\begin{tabular}{|c|c|c|c|}
\hline & GI semptom (-) & GI semptom (+) & P değeri \\
\hline Yaş (yıl) & $37.5 \pm 17.85$ & $47.5 \pm 18.3$ & 0.062 \\
\hline AST (U/L) & $33.7 \pm 29.9$ & $41.2 \pm 24.7$ & 0.051 \\
\hline $\operatorname{ALT}(U / L)$ & $34.5 \pm 47.8$ & $36.3 \pm 23.1$ & 0.382 \\
\hline GGT (U/L) & $38.7 \pm 28.1$ & $39.1 \pm 21.4$ & 0.667 \\
\hline LDH (U/L) & $232.6 \pm 158.5$ & $275.5 \pm 97.9$ & 0.032 \\
\hline T. bil. (mg/dl) & $0.67 \pm 0.27$ & $0.7 \pm 0.35$ & 0.985 \\
\hline D. bil. (mg/dl) & $0.15 \pm 0.09$ & $0.17 \pm 0.11$ & 0.555 \\
\hline CRP (mg/L) & $22.7 \pm 43.1$ & $30.1 \pm 21.2$ & 0.017 \\
\hline D-dimer (ng/ml) & $675.1 \pm 1619.8$ & $1108.9 \pm 1310.9$ & 0.006 \\
\hline $\mathrm{WBC}\left(/ \mathrm{mm}^{3}\right)$ & $7415.3 \pm 2966.9$ & $6093.85 \pm 1935$ & 0.133 \\
\hline Nötrofil $\left(/ \mathrm{mm}^{3}\right)$ & $4642.2 \pm 2733.2$ & $4083 \pm 1617$ & 0.654 \\
\hline Lenfosit $\left(/ \mathrm{mm}^{3}\right)$ & $2007.6 \pm 914.6$ & $1662.3 \pm 484.8$ & 0.175 \\
\hline Monosit $\left(/ \mathrm{mm}^{3}\right)$ & $490.4 \pm 183$ & $415.4 \pm 152.1$ & 0.152 \\
\hline Ferritin (ng/ml) & $223.7 \pm 357.6$ & $370.8 \pm 416.8$ & 0.073 \\
\hline Fibrinogen (mg/dl) & $338.77 \pm 159$ & $475.8 \pm 199.8$ & 0.006 \\
\hline
\end{tabular}

AST: Aspartat aminotransferaz, ALT: Alanin aminotransferaz, GGT: Gama glutamil transpeptidaz, LDH: Laktat dehidrogenaz, T. Bil.: Total bilirübin, D. Bi..: Direkt bilirübin, CRP: C-reaktif protein, WBC: Lökosit. ( $P<0.05$ istatiksel anlamlılık) 


\section{TARTIŞMA}

Çalışmamızın ana bulgularından birisi GI semptomu olan grupta biyokimyasal parametrelerden LDH, CRP, ferritin, fibrinojen ve D-dimer seviyeleri Gl semptomu olmayan gruba göre daha yüksekti. Diğer bir bulgumuz ise Gl semptom varlığı COVID-19'un şiddetini öngörmede yüksek prediktif değere sahipti.

COVID-19 ön planda solunum yolu semptomları ile prezente olsa da azımsanmayacak sayıda hastada GI semptomlar da gösterebilmektedir. Gl tutulum Coronavirus enfeksiyonlarında bilinen bir özellik olup (12) geçmişte yaşanan Severe Acute Respiratory Syndrome (SARS) ve Middle East Respiratory sendromu (MERS) salgınlarında Gl semptomların ön planda olduğu gözlenmiştir (1315). Yapılan bildirimlerde MERS hastalarının yaklaşık \%30'unda diyare olduğu saptanmıştı (16).

COVID-19'un GI semptomlara nasıl neden olduğu tam olarak bilinmemekle birlikte SARS-Cov-2 genomu için anjiotensin konverting enzim-2'nin (ACE-2) viral reseptör olduğu ve ACE-2'nin sadece akciğerde olmadığı, aynı zamanda Gl sistemde de bol miktarda ekspresse edildiği bulunmuştur $(17,18)$. ACE-2'ye bağlanıp hücre içine giren SARS-CoV-2'nin bu şekilde GI semptomlara neden olduğu düşünülmektedir (16). Ancak neden bazı hastalarda Gl semptomlar varken bazı hastalarda olmadığı halen açık değildir. Bu durum; alınan virüs yükü, solunum yollarındaki yetersiz klirens, defans mekanizmalarının eksikliği ve intestinal flora farklılığı ile ilgili olabilir.

Çin'de 651 hasta üzerinde yapılan bir çalışmada hastaların \%11.4'ünde Gl semptom saptanmıştı (8). Bu sonuca benzer şekilde 83 hasta üzerinde yapılan başka bir çalışmada hastaların \%10.1'inde Gl semptom izlenmişti (9). Singapur'da yapılan bir çalışmada ise hastaların \%17'sinde diyare saptanmıştı. Bu çalışmada tüm hastaların dışkısında SARS-CoV-2 genomu araştırılmış ve dışkıda genom varlığı ile Gl semptomlar arasında ilişki saptanmamıştı (19). Çin'de 206 hafif şiddette hastalığı olan hastanın değerlendirildiği bir çalışmada hastaların \%32.5'inde diyare vardı ve bunların \%19.4'ünde diyare ilk semptomdu (7). Yine Çin'de yapılan başka bir çalışmada GI semptom görülme sıklığı oldukça yüksek oranda saptanmış olup hemen hemen hastaların yarısında gözlenmişti ve semptomlar daha çok iştahsızlık ve diyare şeklindeydi (5). Bu çalışmaya benzer şekilde $A B D$ 'de 318 hasta üzerinde yapılan bir çalışmada da GI semptom görülme sıklığı \%61.3 olup diyare \%33.7, bulantı \%26.4 şeklindeydi (10). Son iki çalışmanın da ortak özelliği iştahsızlığı Gl semptom olarak kabul etmeleriydi. Bu nedenle oranları oldukça yüksek çıkmıştı. Görüldüğü gibi COVID-19 hastalarında
Gl semptomların görülme sıklığında birbirinden farklı sonuçlar izlenmektedir. Bu durumun nedeni tam olarak bilinmese de muhtemelen toplumsal beslenme alışkanlıklarındaki farklılıklar, genetik farklılıklar ve çalışma popülasyonlarının farklı demografik özelliklerinden kaynaklanıyor olabilir.

Literatürde GI semptomlarla hastalık şiddeti arasında ilişki olup olmadığı konusunda birbirinden farklı sonuçlar vardır. Pan L ve arkadaşları GI semptom varlığı ile hastalık şiddetinin arttığını bildirmişler ancak sonlanım noktalarına etkisinden bahsetmemişlerdir (5). Jin X ve arkadaşları GI semptomları olan hastaların semptomu olmayanlara göre genel olarak daha yüksek ateş, daha yüksek karaciğer hasarı oranları ve daha şiddetli/kritik hastalığı olduğunu bildirmişlerdir (8). Bu çalışmaların aksine Redd WD ve arkadaşları GI semptomların yatış sonuçlarını etkilemediğini bildirmişlerdir (10). Çalışmamızda COVID-19 şiddeti ile GI semptom varlığı arasında ilişki saptanmış olup, yaptığımız multivaryant lojistik regresyon analizinde GI semptom varlığı hastalığın daha şiddetli olma ihtimalini 7.2 kat arttırıyordu ve bu diğer tüm parametrelerin prediktivite değerinden yüksekti. ICU alınma, mekanik ventilasyon ve ölüm gibi sonlanım noktaları arasında kesin bir istatiksel analiz yapmak için sayımız $(n=6)$ yetersiz olsa da, yine de yaptığımız analizde Gl semptomların sonlanım noktaları üzerine anlamlı etkisi yoktu ( $p=0.539)$.

Çalışmamızın başlıca sınırlılığı görece olarak hasta sayısının az olması ve çalışmanın retrospektif olarak tasarlanmış olmasıydı. Retrospektif tasarlanmasının nedeni olası bulaş riskini önlemekti.

Bildiğimiz kadarıyla çalışmamız ülkemizde COVID-19 hastalarında GI semptomların sıklığını ve prognozla ilişkisini değerlendiren ilk çalışmadır. COVID-19'da solunumsal semptomlara GI semptomlar değişik oranlarda eşlik edebilmektedir. Çok nadiren hastalar sadece GI semptomlar ile başvurabilmektedir. Bu nedenle pandemi döneminde GI semptomu olan hastalarda COVID-19 enfeksiyonu akılda tutulmalı, sağlık çalışanları bu konuda uyanık olmalı ve hastalıktan korunma adına gerekli tedbirlerini almalıdırlar. Yine bu hastaların erken tespit edilmesi ve karantinaya alınması ile hastalığın yayılması da engellenebilecektir. Ayrıca Gl semptomları olan hastalarda hastalığın daha şiddetli olma ihtimali göz önünde bulundurulmalı ve yakın izlem yapılmalı kanaatindeyiz. Çalışmamızın bulgular eşliğinde literatüre katkı sağladığı düşünülmüş olup, bu konuda daha büyük ölçekli çalışmalara intiyaç vardır.

"Tüm yazarlar herhangi bir çıkar çatışması olmadığını beyan ederler." 


\section{KAYNAKLAR}

1. Wang L, Wang Y, Ye D, Liu Q. Review of the 2019 novel Coronavirus (SARS-CoV-2) based on current evidence. Int J Antimicrob Agents 2020;55:105948. Epub 2020 Mar 19.

2. Wu Z, McGoogan JM. Characteristics of and important lessons from the Coronavirus Disease 2019 (COVID-19) outbreak in China: summary of a Report of 72314 cases from the Chinese Center for Disease Control and Prevention. JAMA 2020;323:1239-42.

3. Xiao $F$, Tang $M$, Zheng $X$, et al. Evidence for gastrointestinal infection of SARS-CoV-2. Gastroenterology 2020;158:1831-3.e3. Epub 2020 Mar 3.

4. Gu J, Han B, Wang J. COVID-19: Gastrointestinal manifestations and potential fecal-oral transmission. Gastroenterology 2020;158:1518-9. Epub 2020 March 3.

5. Pan L, Mu M, Yang P, et al. Clinical characteristics of COVID-19 patients with digestive symptoms in Hubei, China: A descriptive, cross-sectional, multicenter study. Am J Gastroenterol 2020;115:766-73.

6. Holshue ML, DeBolt C, Lindquist S, et al. First case of 2019 novel coronavirus in the United States. N Engl J Med 2020;382:929-36.

7. Han C, Duan C, Zhang MD, et al. Digestive symptoms in COVID-19 patients with mild disease severity: Clinical presentation, stool viral RNA testing, and outcomes. Am J Gastroenterol 2020;115:916-23. Epub Apr 15

8. Jin X, Lian JS, Hu JH, et al. Epidemiological, clinical and virological characteristics of 74 cases of coronavirus-infected disease 2019 (COVID-19) with gastrointestinal symptoms Gut 2020;69:1002-9. Epub 2020 Mar 24.

9. Wang D, Hu B, Hu C, et al. Clinical characteristics of 138 hospitalized patients with 2019 novel coronavirus-infected pneumonia in Wuhan, China. JAMA 2020;323:1061-9.

10. Redd WD, Zhou JC, Hathorn KE, et al. Prevalence and characteristics of gastrointestinal symptoms in patients with severe acute respiratory syndrome Coronavirus 2 infection in the United States: A multicenter cohort study. Gastroenterology 2020;159:765-7.e2. Epub 2020 Apr 22
11. Ye Z, Zhang Y, Wang $Y$, Huang Z, Song B. Chest CT manifestations of new coronavirus disease 2019 (COVID-19): a pictorial review. Eur Radiol 2020;30:4381-9. Epub 2020 Mar 19

12. Liu Y, Gayle AA, Wilder-Smith A, Rocklöv J. The reproductive number of COVID-19 is higher compared to SARS coronavirus. J Travel Med 2020;27:taaa021.

13. Lee $N$, Hui $D, W u A$, et al. A major outbreak of severe acute respiratory syndrome in Hong Kong. N Engl J Med 2003;348:1986-94.

14. Leung WK, To KF, Chan PK, et al. Enteric involvement of severe acute respiratory syndrome-associated coronavirus infection. Gastroenterology 2003;125:1011-7.

15. Chan JF, Lau SK, Tos K, Cheng VC, Woo PC, Yuen KY. Middle East respiratory syndrome coronavirus: another zoonotic betacoronavirus causing SARS-like disease. Clin Microbiol Rev 2015;28:465-522.

16. Chan JF-W, Yuan S, Kok KH, et al. A familial cluster of pneumonia associated with the 2019 novel coronavirus indicating person-to-person transmission: a study of a family cluster. Lancet 2020;395:514-23.

17. Zhang H, Kang ZJ, Gong HY, et al. The digestive system is a potential route of 2019-nCov infection: a bioinformatics analysis based on single-cell transcriptomes. Gut 2020;69:1010-8. Published online 2020 Apr 2

18. Liang W, Feng Z, Rao S, et al. Diarrhoea may be underestimated: a missing link in 2019 novel coronavirus. Gut 2020;69:1141-3. Epub 2020 Feb 26.

19. Ong J, Young BE, Ong S. COVID-19 in gastroenterology: a clinical perspective. Gut 2020;69:1144-5. Epub 2020 Mar 20. 